\title{
Gender, Class and Bureaucratic Power: The Production of Inequalities in the French Civil Service
}

\author{
Anne Revillard \\ Sciences-Po, OSC-LIEPP \\ anne.revillard@sciencespo.fr \\ Alban Jacquemart \\ Université Paris-Dauphine, IRISSO \\ alban.jacquemart@gmail.com
}

\section{Laure Bereni, Sophie Pochic, Catherine Marry \\ laure.bereni@cnrs.fr; sophie.pochic@ens.fr; Marry.catherine@orange.fr}

\begin{abstract}
This article examines the logics behind the tenacious persistence of gender inequalities in French civil service careers, based on 95 biographical interviews conducted with civil servants in upper-middle management and executive positions between 2011 and 2013. The study combines attention to the consequences of the organizational context with analysis of the interplay between gender and class, particularly focusing on how managers and executives appropriate equality policies. While family background has differential impacts on women's and men's educational paths and orientations, we find that governmental administrative bureaucracies also make strong contributions to the production of such differences through the rules and norms that equality policy struggles to change, especially in a time of austerity and deepening "new public management" reforms. While most managers and executives of both sexes tend to deny the organizational and social causes of inequality, the diffusion of egalitarian norms fosters the expression of gender consciousness by a minority of women, and reshapes mainstream managerial masculinities and femininities.
\end{abstract}

Keywords: Gender, bureaucracy, inequalities, France. 
Resumen: Este artículo examina las lógicas detrás de la tenaz persistencia de las desigualdades de género en las carreras del servicio público en Francia, basado en 95 entrevistas biográficas realizadas con funcionarios en puestos de alta dirección y ejecutivos entre 2011 y 2013. El estudio combina la atención a las consecuencias del contexto organizacional con análisis de la interacción entre género y clase, centrándose especialmente en la forma en que los gerentes y los ejecutivos se apropian de las politicas de igualdad. Si bien los antecedentes familiares tienen impactos diferenciales en las trayectorias y orientaciones educativas de mujeres y hombres, encontramos que las burocracias administrativas gubernamentales también contribuyen fuertemente a la producción de tales diferencias a través de las reglas y normas que las politicas de igualdad luchan por cambiar, especialmente en tiempos de austeridad e intensificación de las reformas de la "nueva gestión pública". Si bien la mayoría de los gerentes y ejecutivos de ambos sexos tienden a negar las causas organizativas y sociales de la desigualdad, la difusión de normas igualitarias fomenta la expresión de la conciencia de género por una minoría de mujeres y reestructura las masculinidades y feminidades gerenciales.

Palabras clave: género, burocracia, desigualdades, Francia. 


\section{Introduction}

The glass ceiling remains a reality in the French civil service, despite formally neutral rules for hiring and management and the attendant guarantees of government employee status that determine career paths and pay. ${ }^{1}$ Although the majority of government employees (middle management positions included) are women, they only held $30 \%$ of senior executive positions in $2014 .{ }^{2}$ This article examines the logics behind this tenacious persistence of gender inequalities in careers in the French civil service. It presents the main findings of a study conducted from 2011 to $2013,{ }^{3}$ primarily consisting of 95 biographical interviews with civil servants in upper middle-management and executive positions in the Ministry for the Economy and Finance and the Ministry for Social Affairs (Marry et alii, 2017). The research setting was affected by the diffusion of "new public management" (managerial principles imported from the private sector) and the development of gender equality policies targetting the higher echelons of civil service. In 2012, a law instated gradual quotas to feminize higher governmental leadership positions ( $20 \%$ by $2014,40 \%$ by 2017 ), following the example of the executive boards of large private companies. ${ }^{4}$

This study builds upon prior research exposing the social and organizational logics that foster gender inequalities. Our research began with three main orientations: 1) to be attentive to the impact of the organizational context; 2) to analyze the combined effects of gender and class in the construction of professional hierarchies; and 3) to focus on how managers and executives appropriate equality policies.

The article first reviews relevant contributions from gender, organizational, and career studies, and then presents our research methods. This is followed by our study's main findings, which shed light on the processes (re)producing the glass ceiling. For one thing, family upbringing leaves traces on educational paths and orientations that differ between women and men. But governmental administrations also contribute to the production of these differences through

1 This article is a substantially updated version of a previous publication in French: Marry, Catherine, Bereni, Laure, Jacquemart, Alban, Le Mancq, Fanny, Pochic, Sophie and Revillard, Anne (2015). "Le genre des administrations. La fabrication des inégalités de carrière entre hommes et femmes dans la haute fonction publique". Revue Française d'Administration Publique, 153: 45-68.

2 This comes from data provided by the Direction générale de l'administration et de la fonction publique (DGAFP; Administration and Civil Service Division), for the category "encadrement supérieur et emplois de direction" (upper management and executive positions). The category counts approximately 10,000 of the 2,400,000 civil servants in France.

3 This research was funded by the DGAFP.

4 A 2011 law imposed the phasing in of gender quotas in the composition of the executive boards of large companies. 
the rules and norms that equality policy struggles to change, all the more so in a time of austerity. Managers and executives of both genders tend to deny the organizational and social causes of inequality. A minority of women has nevertheless begun to protest the masculine domination in the government's highest ranks, and the gender identities of women as well as men are being reshaped as the egalitarian norm gains momentum.

\section{Gender, organizations, and careers}

A vast body of literature has developped over the past 30 years exploring the social logics behind women and men's unequal access to the most prestigious professional positions, a phenomenon often described with the metaphor of the "glass ceiling."

Interpretations of these inequalities have gradually shifted from attributing them to the presumed lesser ambitions of women due to their childhood socialization and the constraints of their "double lives" (an interpretation referred to as self-censorship) and toward the advantages that men enjoy at every step of their lives. From early childhood to the schoolyard and classroom and on to the variety of jobs they are offered, men learn self-confidence more readily than women, along with how to take risks, compete with rivals, develop friendships and bonds with male colleagues likely to offer them better jobs, and most of all, devote themselves to their work and career without counting the hours. Unlike men, very few women, regardless of how impressive they may be, can benefit from the unconditional support of a stay-at-home spouse or one only working part time, thus freeing them from the contingencies of domestic life and ensuring them voluntary support for pursuing their occupation (Gadéa \& Marry, 2000; Wajcman, 1998). Consequently, only women with resources that are as extraordinary for women as they are for men are able to break the glass ceiling: flawless academic performance, an egalitarian upbringing, and the support of their immediate family and spouse (Pigeyre, 2001; Marry, 2004).

Exploring labor organizational and management policies, other research has revealed deeply rooted "gender biases" within administrations and businesses that hamper women's access to the highest positions. They expose the influence of organizational norms and practices on gendered career inequalities (Kanter, 1977; Laufer, 1982; Wajcman, 1998; Fortino, 1999; Laufer, 2004). Based on such work, Joan Acker (2009) suggested using the term "inequality regimes" to describe the range of organizational processes that produce hierarchies and inequalities (both gendered and ethno-racial) in all human resource management activities: hiring, promotion, job classification systems, wage setting, supervisory practices. 
Gender biases are partly embedded in formal career management principles, which seem neutral but are actually based on a male referent, including strict age criteria for promotional eligibility, expectations of repeated geographical relocations, work experience in operations, ability to work long and flexible hours, and greater esteem for certain male-dominated scientific degrees. But gender biases are also ingrained in informal norms and procedures for selecting or excluding mid-level managers from executive positions (influence of networks of cooptation, possessing "good" leadership qualities such as being completely available, charismatic, authoritarian, competitive). This work highlights the dynamic and processual qualities of the selection and socialization experiences that make the highest positions a possibility. They furthermore change according to the organizational context, and are affected by restructuring processes, a variability not captured by the static metaphor of the glass ceiling (Pochic $\&$ Guillaume, 2009; Halford et alii, 1997).

A few studies have specifically addressed gender inequalities in the French civil service, emphasizing the similarities and differences between the public and private sectors (Milewski, 2004; Le Douarin \& Doniol-Shaw, 2008; Alber, 2013). At first view, the bureaucratic and meritocratic rules governing hiring, pay, and promotion usually make the civil service seem more egalitarian and propitious for women's careers. Historical research has nonetheless demonstrated that this principle of equality is relatively recent, and that numerous legal obstacles excluded women from the highest civil service positions until the mid-twentieth century (Rennes, 2007). Women had relatively early access to positions of responsibility in some governmental administrations, but only in very limited fields and for tasks supposedly suited to their sex. For instance, women began to be present in state social services in the late nineteenth century (Schweitzer, 2010). The École Nationale d'Administration (ENA, National School of Administration), which selects its students through a highly competitive entrance examination and paves their way to the most prestigious civil service positions, has been co-ed since it was founded in 1945. Women were long a small minority of the student body, however, and still only comprise about a third of the entering classes of 2000 through 2010. But despite affirmations of the principle of gender equality and the implementation of policies intended to make it a reality, the civil service still falls short in offering women the same professional opportunities as men (Alber, 2013).

The mechanisms contributing to gender inequality in careers have moreover been affected by the spread of "new public management," which began in the early 2000s (Bezes, 2012). Civil service "human resource management" is being individualized, modeled after private-sector practices, at a time of budgetary 
austerity and gradual reduction of the number of government employees. At the same time, equal employment policies have developed in continuity with recently adopted political parity laws requiring and motivating political parties to run an equal number of men and women in most elections (Bereni \& Revillard, 2007). Research on the implementation of these policies has underscored organizations' ability to adapt to these legal constraints while still maintaining inequality by establishing symbolic structures that are dissociated from organizational routine (Meyer \& Rowan, 1977; Cockburn, 1991; Edelman, 2016). These policies moreover tend only to benefit a small elite of women and only marginally destabilize career model-types (Jacquemart et alii, 2016). Some governmental administrations even developed early policies for feminizing their organizational charts "from above," as happened with police commissioners, in order to burnish the reputation of a much-criticized institution (Pruvost, 2007).

\section{Methods}

To follow up on such work, we focused on the mechanisms producing and maintaining the glass ceiling by considering the social trajectories of high-ranking managers and senior executives, the professional norms and operating rules in the studied administrations, and women's strategies to conform.

The study primarily consists of biographical interviews with women and men holding upper management and executive positions in state services, working either in a central, national-level office in Paris or a local-level branch elsewhere in France. A total of 95 interviews were conducted between August 2011 and August 2012, two thirds with women and one third with men. Interviews lasted from one to three hours, and were recorded and fully transcribed.

Research participants' profiles reflect the range of hierarchical levels, ages, generations, degrees, social backgrounds, and family configurations found among the category of civil servants being studied. We interviewed senior executives, but also people holding higher management-level positions; this is generally the pool from which future executives are chosen, and indeed many of those interviewed aspired to senior executive positions later in their careers. We took care to interview people with different career paths. Passing the entrance examination to the highly selective and prestigious ENA is the fast track for reaching powerful positions, offering a protected and speedy path upward, but some high-ranking officials took another path, entering the civil service through a lower-level management examination and then successfully navigating a string of civil service exams over their careers to gradually climb the ranks to greater responsibilities. This is why only one third of our sample consists of ENA graduates (see Career Types box). 
We met our interviewees in two government ministries, the Ministry for the Economy and Finance and the Ministry for Social Affairs. The former is associated with sovereign functions evoking professional traits commonly understood as masculine and prestigious (such as authority, rigorousness, technical skill) and its top echelons only began to feminize recently, and to a limited extent. The latter, to the contrary, intervenes in domains seen as feminine and less prestigious (such as the family, care, poverty, and disability), and its top ranks are more feminized. The aim was thus to study mechanisms producing the glass ceiling in ministerial administrations associated with either masculine or feminine symbolic connotations.

The study also included the analysis of institutional documents acquired from various interviewees: reports on equality, gendered statistics, organizational charts, policy documents concerning diversity and equal employment, and internal communications in many forms. This documentation helped us to contextualize careers in specific organizational settings, and to analyze the unfolding of equality programs.

\section{Career types in the Ministries for the Economy and for Social Affairs}

We identified four major career types giving faster or slower access to high-ranking managerial and executive positions in the studied ministerial organizations.

The first type goes through ENA, by either so-called "external" examination (in the continuity of their studies at age 22-24) or "internal" examination (around age 30 , for candidates already working in the civil service). This path, especially the external variant, is the fastest and surest to reaching one of the prestigious corps (notably that of Civil Administrators).

The second type joins the Civil Administrator corps by taking the "outside path" (tour extérieur, or TourEx for short). It allows civil servants in middlemanagement positions (particularly that of Principal Officer) to join this corps mid-career, around age 40, and to thus avoid hitting a career ceiling.

The third type, which we call "in-house career," consists of internal promotions within some specific ministries. It offers great careers to a small number of civil servants who entered through mid-level ministry-specific civil service examinations. This internal professional ascension within one organization is nonetheless a long process and in the best of cases only makes it possible to reach an executive position in the latter part of the career - and only in the decentralized services of the concerned ministry.

The fourth type includes a rather diverse category of civil servants that had passed other A-Category civil service exams or were hired on contract for their expertise in a given area. This is the least likely path to reaching an executive position. 


\section{Results}

The study's most prominent results concern the effects of gender and class socialization prior to embarcking on a career (1), gender bias in work and career norms (2), the very unequal weight of the work-family "balance" (3), and the widely shared belief that the civil service discriminates less against women than the private sector (4).

\section{Before careers start: the mark of class and gender}

The gendered hierarchy of governmental administrations partly derives from mechanisms of socialization at work well before the career, starting with early education. Indeed, French civil service careers are largely determined by competitive examinations to enter the ranks, with a key division between those who attend ENA and those who do not. The careers of those who passed the ENA exam, particularly the "external" exam taken in one's early 20s, benefit from considerable guarantees in terms of career advancement. Those who did not attend ENA but still aspire to high managerial and executive positions must follow long, obstacle-filled paths their whole career, and very few will succeed.

Passing the ENA examination is highly correlated to social class and gender Studies of the social recruitment of students for the grandes écoles (the highly selective and thus prestigious public institutions for higher learning, such as ENA) and members of the great administrative corps highlight the overrepresentation of children from the upper social classes (Bourdieu, 1998; Euriat \& Thélot, 1995; Ferrand et alii 1999; Eymeri, 2001). Although an interviewee's use of the term "Hindu castes" may seem excessive for describing the airtight social hierarchy of career tracks, they do indeed correlate with class background. Only $10 \%$ of the ENA graduates (commonly known as énarques) in our sample come from working-class families, while this is the background of nearly a third of those rising through TourEx and nearly half of those advancing "in-house" (see box). Most internal or external ENA graduates, who are more likely to reach executive positions and to do so more rapidly, come from upperclass backgrounds with parents working in the public or private sector. Lastly, for all paths (but especially the "in-house" route), coming from a civil-service family gives a meaningful advantage (Singly \& Thélot, 1988). Our study thus confirms that class background is still influential on educational and professional futures.

Gender also plays a critical role. First of all, despite a better average academic performance, even today women are less likely to attend the elite grandes écoles that offer privileged access to positions of power in France. While women's 
enrolment rate at ENA has been one in three students since the early 2000s, it has not kept pace with enrolment in the Instituts d'Etudes Politiques (IEP, Institute of Political Studies), which are selective universities specialized in political and administrative sciences and the usual source of ENA applicants. Indeed, ENA's entrance examination is still unfavorable to women: on average, between 1999 and 2012, women were 42\% of ENA applicants, but only 32\% of those passing the exam (Siwek-Pouydesseau, 2013). Gender inequalities in careers are thus partly determined at the earliest entry phase of the career, the initial entrance examination.

Furthermore, women making it into a grande école do not have the same social profile as their male peers. There is an over-selection of women from high social strata, a phenomenon that was even more striking among the first pioneering generations of women integrating higher professions (Boigeol, 1996; Marry, 2004; Rouban, 2013). Our study confirms that this is still the case: $52 \%$ of female ENA graduates in our sample come from an upper-class family, in contrast with $12.5 \%$ of their male peers.

In addition to particularly high class backgrounds, young women who get into grandes écoles have often enjoyed a rather egalitarian upbringing in terms of gender. Families of all social milieus still generally have higher professional and social expectations for boys than for girls and encourage or even pressure boys to pursue selective academic options more than they do girls. Our interviewees' families are no exception, but some of our female interviewees were raised in egalitarian or feminist families, and were encouraged as much as their brothers (or for lack of boys in the family) to take their chances in committing to the most selective academic tracks. For those from the working classes, such an upbringing gave them the ambition and courage to pass internal examinations throughout their long careers. Women's accounts often mention their mothers' support, in some cases passing on their own frustrated academic and career ambitions. Some young women see a career in government administration as an especially appealing alternative to teaching, which is widely thought to be "so good for women" in the working and middle classes.

Academic excellence (which is heavily reliant on class background), a genderegalitarian upbringing, and a desire to escape teaching thus work in favor of women's access to the elite grandes écoles and successful passage of the most prestigious entrance examinations, especially ENA's. Such success protects this handful of women from everyday discrimination and offers them much wider career prospects, as this female ENA graduate stressed: "I think that, for a woman [...], having attended ENA is extremely protective, because in our 
society of castes and degrees, the legitimacy of having gone to ENA $[\ldots]$ is more important than the gender deficit in the world of the civil service." The added value of this degree contributes to their self-confidence, and indeed not a single ENA graduate in our study reported having refused a bureau chief position because they felt a lack of legitimacy or availability, although women on other career tracks are more prone to hesitation.

Attending ENA is not necessarily enough to offer women the same careers as men, however, as their choices of first postings attest. Women tend to choose ministries in charge of social issues, claiming a vocation for the relevant policy area regardless of the lesser prestige of social matters, thus resulting in lowered career prospects. This comes from the differential socialization of girls and boys, leading women to have a stronger taste for social issues, to the point that some female ENA graduates choose social ministries even when their ranking gives them access to a more prestigious one. We have never heard a comparable reference to a "vocation" for economic and financial affairs, and neither have we met men who would have chosen a socially oriented ministry if their ranking had allowed a more prestigious posting.

\section{Work and career norms that still disfavor women}

Although gender inequalities in careers start with the first civil service examination, they are exacerbated by hiring and promotion norms.

These inequalities are first of all manifest in a gendered division of labor within organizations. A range of orientation and assignment procedures usually assigns women to positions of expertise, which are much less valued than managerial positions, with decisive consequences for career advancement (Savage \& Witz, 1992).

Requirements that employees be available for long workdays or accept repeated transfers around the country also weigh heavily against women. The positions we studied demand long working hours. Our interviewees arrive at work between $8: 30$ and 9:30 in the morning and often leave between 7:30 and 8:30 at night, or even later for some in positions of great responsibility. One of the divisions we studied in the Ministry for the Economy and Finance is particularly demanding. Ministerial cabinets' demands on administration staff contribute significantly to the irregularity of working hours. Because of the unequal division of domestic labor, balancing this workload with personnal life is much more challenging for women, particularly those with children, than it is for men regardless of their parental status. As a result, women (and a few men) may turn down executive and cabinet positions partly in anticipation of such excessive hourly demands. 
Perceptions of a position's workload and demands also vary with the individual's initial socialization and the kind of schooling they had: growing up in an upper-class intellectual family and taking an academic path requiring supplementary study in programs preparing them for selective entrance exams leading them to an IEP (or the Ecole Normale Supérieur, ENS) provides some ease from the demands of government work as well as some critical distance from its norms. The reverse tends to be true for those from working-class backgrounds and/or those who came to government work via a lower-level civil service exam, conditions that favor extreme conformity to norms and multiply the likelihood (for women in particular) of feeling illegitimate or incompetent for a position thought to be particularly demanding. We cite, for instance, the case of a woman who became a civil servant through a low-level civil service exam and was later offered a promotion at a time when she was having family problems (as an only child she had to care for her parents, who had become dependent). She turned down the position, thinking that she did not "know how to do it": "it's impossible for me, in these conditions, I think, to commit to a new [higher-level] position, [it's] much wider territory, different ways of working, [... $]$ I think that I don't know how to do it" (woman, about 60).

Likewise, the geographical mobility required of certain careers is a very strong hindrance to women (Guillaume, Pochic, 2009; Cartier \& Join-Lambert, 2011). Civil servants who went through ENA can attain executive positions in the central administration without ever having to leave greater Paris, but management-level workers in decentralized services elsewhere in France cannot climb the ranks of their corps to its executive level without going through multiple onerous relocations to different parts of the country. Men are more likely to subject themselves to this norm, and are often followed by their wives, who sometimes sacrifice their careers to do so. Women, however, accumulate obstacles that commonly divert them from this path: the reticence of partners (often management-level themselves, in the private or public sector), weakened family networks (precious support for childcare), and guilt and social reprobation for mothers choosing "geographical celibacy." Women's mobility is still subject to many conditions not experienced by men, starting with the priority given to their spouses' careers, as we can see in this interviewee's case: "If he ever has any problems or anything in his career, we might be able to think about moving, it'll depend on him. But for now, today, he's not mobile" (woman in her forties).

Careers in governmental administration also heavily rely on relations of cooptation rooted in interpersonal connections, since informational and support networks, reputation, and confidence are all built in a closed professional universe. 
But behind these relations of cooptation, recommendation, and personal support are gender biases (Fortino, 1999; Guillaume \& Pochic, 2009). These networks are generally built after working hours and based in male sociability. One manageriallevel interviewee pointedly indicated that her division has "a complicity, which we are excluded from as women. They go out at night, they go for drinks at the bar next door... Me, when I leave at night, I go home. They do stuff together, they play soccer - my god, the soccer! They made a soccer team." The fact that cooptation passes through peer recommendations to ranking superiors will continue to favor men, so long as the higher ranks are held primarily by men. This system is exacerbated for reaching ministerial cabinet positions, a decisive step for the most illustrious careers.

The study suggests that the austerity policies and reorganization that hit the French civil service since the late 2000s, following the example of corporate restructuring and downsizing (Pochic \& Guillaume, 2009), are propitious to reproducing class and gender inequalities. Because these reforms led to the regrouping of services and a reduction in the number of hierarchical echelons, they increase competition for access to higher positions. This has a particularly strong impact on mid-level managers not having attended ENA. In the past they could aspire to a rising career within their ministry (TourEx and "inhouse" in the box above), but today their career perspectives have been reduced under heightened competition. This shrinking of the structure of opportunities for ascension is especially threatening for women not having attended ENA. Reduced opportunities for promotion are rarely interpreted as a "women's problem," however, because many divisions now have as many women as men (if not more). They also think that their male colleagues might be in the same situation, since they, too, are faced with negotiating their careers with their wives or partners, when both are professionally active.

\section{3. "Reconciling" work and family, with unequal results}

Many of the civil servants (both men and women) we interviewed have two or three children, and have pursued their careers without interruption since they first began. Our study sheds light on the unequal consequences of work/family interactions at two temporal scales - the connection between birth timing and career, and the everyday weight of this reconciliation.

There is first of all an observable difference in how professional calendars and birth calendars interact for women and men. Men do not plan parenthood according to their professional careers, and the arrival of children has no obvious effect on their careers or choice of position. They may thus have children while 
they are still in school or posted abroad, far from their partners, or when then are taking a civil service exam preparation course several hours from home, as in the following case: "I'd spend about eight hours a day in the train every day [to get to the preparatory class] but it was a commitment: I said, we'd just had our first child, she absolutely wanted me at home, but I absolutely wanted to get into management" (man, around forty). Inversely, women with or hoping to have children (nearly all in our sample) revealed a close connection between planning pregnancy and their professional calendars. It is all but impossible to have a child while still in school (Bajos \& Ferrand, 2006), so the best time has to be found later. One strategy is to avoid having "more than one child during a given posting" (as one interviewee phrased it) so as not to overly disrupt their working patterns and compromise their chances of promotion, and sometimes women may time pregnancies between successive postings. Women thus start "balancing" before even having children in an effort to minimize possible consequences on their careers, while births have no observable effect on the professional activity of fathers.

From this perspective, our interviewees' accounts of maternity leave shed light on the injunctions weighing on women to reconcile their careers and family life, confirming that having a legally recognized right does not ensure its effectiveness (Bui-Xuan, 2011). The legally mandated maternity leave in France may be 16 weeks (or 26 weeks with the third and subsequent children), but interviewees describe a more complex picture: starting maternity leave later than was medically advised, resuming work by telecommuting while still formally on leave, having no maternity replacement, or being marginalized upon returning to work. The following quote is thus an example of how one woman's desire to respond to her superiors' expectations and fear of "floundering" when she went back led her to give up the effective benefits of her right to leave: "[I went on leave] shortly before giving birth, and even after, out of the office, I was on my phone, computer [... ] Colleagues could call me when they wanted [...] I knew it was more practical for my superior [...] and for me that way. It also let me tell myself that I was sure to be able to get immediately back in gear and not flounder when I returned" (woman in her 30s). Another interviewee eloquently presented her strategy for changing positions at the time of each pregnancy as a way to not have to "pay for" her maternity leave. So many challenges not faced by men, from whom we heard no direct account of full or part-time paternity leave with troubling professional consequences.

The unequal effects of reconciliation also have an impact on everyday life. The extensive delegation of daily childcare for preschool-aged children to daycare, 
home-based childcare providers, grandparents, and/or babysitters does not mean that mothers are freed of worry about it, and they bear nearly all the "mental load" (Haicault, 1984). The difficulties and guilt, not to mention the risk of overwork and exhaustion, are distinctly higher for women than for men.

The study also demonstrated that this care work does not taper off as children get older. To the contrary, the norm of the mother-educator expected to supervise her children's homework (especially in high school, so they can get into a selective track of higher education) is a significant burden on this population. One interviewee recalled it this way: II made [my children] recite their lessons at seven in the morning and I re-read their homework at two in the morning, when I got home" (woman in her 60s). Maternal investment in children's educational success continues or even increases women's need for striking a balance, while children's education does not seem to affect fathers' work. Likewise, care for ill or dependent parents has a markedly stronger impact on women's careers, particularly for women from a working-class background. This expected overinvestment of women in the private sphere is thus not without consequence on their careers, especially in professional settings demanding they be available to work long hours and/or relocate.

While it is experienced and overcome in a range of ways, depending on social background, generation, age, family configuration, or which civil service exam was taken, reconciling work and family is overwhelmingly seen as a personal responsibility, and its consequences are considered to be the legitimate responsibility of individuals. This is the case in relation to spouses, in line with the classic model holding that husbands can only "help," but also in relation to how work is managed, requirements of professional overinvestment being only rarely challenged as people endeavor to cope by rearranging their personal lives.

\section{From denial of inequality to egalitarian awareness}

This study was conducted in a context of increasingly demanding equality policy, which established gender quotas in the appointment of executive managers and soft law measures such as the Diversity and Equality Labels, state awards distinguishing "good practices" combating discrimination in the workplace. ${ }^{5}$ This context made it possible for us to question interviewees on their perceptions of the new policies as well as gender relations.

Our first observation is that women as well as men euphemize or even deny the existence of gender inequalities. They believe that the civil service operates in a way that protects them from all kinds of discrimination (through its

5 In 2016, 17 public organizations had the Diversity Label and 9 the Equality Label. 
exams, system of echelons and grades, guarantee of employment), especially in comparison with the private sector: "In the civil service [... $]$ there is legal equality. We earn exactly the same thing, we can pass exactly the same exams [...] I think that everyone really has the same chances, honestly" (woman in her 40s). When inequalities are acknowledged, they are described as relics of the past or attributed to "personal choices" or gender norms thought to be external to the organization.

This euphemization of inequalities does not, however, mean that women have a neutral view of their professional world or of themselves. In an organisational setting where executive positions are still primarily held by men and associated with hegemonic masculine qualities, women adapt to this norm using gender performance, semi-consciously staging and modulating their gender identity accordingly (Goffman, 1977; Butler, 1990). Their accounts notably reveal strategies for neutralizing femininity and conforming to hegemonic masculine qualities that are common among women working in typically male bureaucratic environments (Laufer, 1982; Wajcman, 1998; Pruvost, 2007; Le Feuvre, 2008).

Equality policy is not without its consequences on these gender performances. As found in studies in the field of politics with the introduction of the political parity law (Achin et alii, 2007), we noted some strategic and circumstantial uses of femininity, whose associated traits can, from time to time, be used in the exercise of power. Moreover, in the context of equal employment policies, a new legitimate figure for female executives appeared: the "normal woman," who has a successful professional career while also "keeping her femininity" (through her appearances, values traditionally associated with women, and/or a heterosexual domestic arrangement including children).

At the same time, some of the men we interviewed try to perform the figure of the "modern man" committed to gender equality, in opposition to "traditional" masculinity that is now thought to be outdated. These men, most born in the 1970 s or since, are thus eager to emphasize their "good" and "women-friendly" professional practices in interviews. In a stereotypically masculine register, the bureau chief cited below has made equality into a sort of competition, describing himself as its "champion": "I am the world champion of maternity, though, because I had two maternity leaves in a row [in my department], so two maternity leaves in three years, and I've just hired a young middle manager who was pregnant when I hired her" (man in his 20s).

Public policy implementation is also a propitious time for criticizing gender inequalities. Some women do assert some form of gender consciousness (Klein, 1984; Rinehart, 1992) or even a feminist identity that could barely be expressed previously, but this egalitarian consciousness is only found in a minority, and 
remains limited. This awareness is more common in women than men, and among women, more common among female ENA graduates. It can only be publicly stated while asserting a distance from "activism" and "feminism" references that are still powerfully stigmatizing in France, in public and private organizations alike.

\section{Conclusion}

Our study of nearly 100 life histories allows a better understanding of obstacles in women's careers and the times and places when they are most significant. The glass ceiling results from a long process, starting with socialization in the family and continuing throughout the career, a product of the private sphere as much as the professional. Women's family backgrounds and how they were oriented in school lead to unequal resources. Generally less supported by their families and less likely to follow the most professionally advantageous educational paths, women need to have particular advantages (like being an exceptional student and/or raised in an egalitarian way) in order to have a chance at achieving careers comparable to those of men.

But there is also an organizational dimension to the glass ceiling's existence, as the study of career norms reveals. Beyond the gender biases introduced by the overvaluing of rare and prestigious degrees (ENA), temporal and geographical constraints, linear and rapidly ascending career models, and the role of cooptation, are all explicit or implicit norms favoring men over women for access to the highest positions. These unequal career opportunities are reinforced by the opposing effects of married and family life, which are a source of support for men but difficulty for women given the masculine organizational norms still present in the workplace. And although equality policies provide tools for naming and rejecting gender inequalities, the persistent euphemization of these inequalities contributes to legitimating and strengthening the glass ceiling. Ultimately, in France as elsewhere, the restructuring of public services under budgetary constraint has had disproportionate consequences on the careers of women in the lower and middle echelons, running counter to the egalitarian agenda now vaunted by administration elites (Conley, Kerfoot, Thornley, 2011). 


\section{References}

Achin, Catherine; Bargel, Lucie; Dulong, Delphine and Fassin, Eric (2007). Sexes, genre et politique. Paris: Economica.

Acker, Joan (2009). "From glass ceilings to inequality regimes". Sociologie du Travail, 51 (2): 199-217.

Alber, Alex (2013).“Un plafond de verre plus bas dans la fonction publique? Une comparaison public/privé de l'accès des femmes aux fonctions d'encadrement". Travail, Genre et Sociétés, 30: 131-154.

Bajos, Nathalie and Ferrand, Michèle (2006). "Linterruption volontaire de grossesse et la recomposition de la norme procréative". Sociétés Contemporaines, 61:91-117.

Bereni, Laure, and Revillard, Anne (2007)."Des quotas à la parité : 'féminisme d'État' et représentation politique (1974-2007)". Genèses, 67: 5-23.

Bezes, Philippe (2012). "État, experts et savoirs néomanagériaux. Les producteurs et diffuseurs du New Public Management en France depuis les années 1970". Actes de la Recherche en Sciences Sociales, 193: 16-37.

Bourdieu, Pierre (1998[1989]). The State Nobility: Elite Schools in the Field of Power. Translated by L. Clough. Stanford: Stanford University Press.

Bui-Xuan, Olivia (2011)."Le congé de maternité des enseignantes-chercheures". Droit et société, 77: 111-136.

Butler, Judith (1990). Gender Trouble: Feminism and the Subversion of Identity. New York: Routledge.

Cartier, Marie, and Join-Lambert, Odile (2011). "Promotions et migrations administratives histoire, ethnographie, approches croisées". Travail et Emploi, 127: 5-14.

Cockburn, Cynthia (1991). In the Way of Women: Men's Resistance to Sex Equality in Organizations. London: Macmillan.

Conley, Hazel; Kerfoot, Deborah, and Thornley, Carole (2011). "Gender Equality and Modernization of Public Sector Employment". Gender, Work \& Organization, 18 (5): 439-442.

Edel, Frédéric (2013). "Les instruments juridiques de l'égal accès des femmes et des hommes aux emplois publics : depuis le droit à l'égalité jusquaux politiques d'égalité ". Revue Française d'Administration Publique, 145: 109-135.

Edelman, Lauren B. (2016). Working Law. Courts, Corporations and Symbolic Civil Rights. Chicago: University of Chicago Press.

Euriat, Michel, and ThÉLot, Claude (1995). "Le recrutement social de lélite scolaire en France. Evolution des inégalités de 1950 à 1990”. Revue Française de Sociologie, 36: 403-438. 
Eymeri, Jean-Michel (2001). La fabrique des énarques. Paris: Economica.

Ferrand, Michèle; Imbert, Françoise, and Marry, Catherine (1999). L'excellence scolaire, une affaire de famille. L'exemple des normaliennes et normaliens scientifiques. Paris: L'Harmattan.

Fortino, Sabine (1999). "De la ségrégation sexuelle des postes à la mixité au travail : étude d'un processus". Sociologie du Travail, 41:363-384.

Gadéa, Charles, and Marry, Catherine (2000). "Les pères qui gagnent : descendance et réussite professionnelle chez les ingénieurs". Travail, Genre et Sociétés, 3: 109-135.

Goffman, Erving (1977). "The Arrangement between the Sexes". Theory and Society, $4(3) \div 301-331$.

Guillaume, Cécile, and Pochic, Sophie (2009). "What would you sacrifice? Access to top management and the work/life balance". Gender, Work and Organization, 16 (1): 14-36.

Haicault, Monique (1984). "La gestion ordinaire de la vie en deux". Sociologie du Travail, 3: 268-277.

Halford, Susan; Savage, Mike, and Witz, Anne. (1997). Gender, Careers and Organisations: Current Developments in Banking, Nursing and Local Government. London: Macmillan.

Jacquemart, Alban; Le Mance, Fanny, and Pochic, Sophie (2016). "Femmes hautes fonctionnaires en France. L'avènement d'une égalité élitiste". Travail, genre et sociétés, 35: 27-45.

Kanter, Rosabeth Moss (1977). Men and Women of the Corporation. New York: Basic Books.

Klein, Ethel (1984). Gender Politics: From Consciousness to Mass Politics. Cambridge MA: Harvard University Press.

LAufer, Jacqueline (1982). La féminité neutralisée. Les femmes cadres dans l'entreprise. Paris: Flammarion.

- (2004). "Femmes et carrières : la question du plafond de verre". Revue Française de Gestion, 30 (151): 117-127.

Le Douarin, Laurence, and Doniol-Shaw, Ghislaine (2008). "Laccès des femmes aux emplois supérieurs de la fonction publique : une construction au croisement des itinéraires professionnels et familiaux". Politiques et Management Public, 26 (2): 75-97.

Le Feuvre, Nicky (2008). "La féminisation des anciens bastions masculins. Enjeux sociaux et approches sociologiques". In Yvonne Guichard-Claudic, Danièle Kergoat, and Alain Vilbrod (eds). L'inversion du genre : Quand 
les métiers masculins se conjuguent au féminin... et réciproquement. Rennes: Presses Universitaires de Rennes.

Marry, Catherine (2004). Les femmes ingénieurs. Une révolution respectueuse. Paris: Belin.

Marry, Catherine; Bereni, Laure; Jacquemart, Alban; Pochic, Sophie, and Revillard, Anne (2017). Le plafond de verre et l'Etat. La construction des inégalités de genre dans la fonction publique. Paris: Armand Colin.

Meyer, John W., and Rowan, Brian (1977). "Institutionalized Organizations:

Formal Structure as Myth and Ceremony". American Journal of Sociology, 83 (2):340-63.

Milewski, Françoise (2004). "Linégalité entre les femmes et les hommes dans la haute fonction publique". Travail, genre et sociétés, 12: 203-212.

Pigeyre, Frédérique (2001). "Femme dirigeantes, les chemins du pouvoir". In Bouffartigue, Paul (ed.). Cadres, la grande rupture. Paris: La Découverte.

Pochic, Sophie and Guillaume, Cécile (2009). "Les carrières des cadres au cour des restructurations : l'ambivalence des effets de genre". Sociologie $d u$ Travail, 51 (2): 275-299.

Pruvost, Geneviève (2007). "La dynamique des professions à l'épreuve de la féminisation : l'ascension atypique des femmes commissaires". Sociologie $d u$ Travail, 49 (1): 84-99.

Rennes, Juliette (2007). Le mérite et la nature. Une controverse républicaine : laccès des femmes aux professions de prestige 1880-1940. Paris: Fayard.

Rinehart, Sue-Tolleson (1992). Gender Consciousness and Politics. New York: Routledge.

Rouban, Luc (2013). "Laccès des femmes aux postes dirigeants de l'État". Revue Française d'Administration Publique, 145 : 89-108.

Savage, Michael, and Witz, Anne (1992). Gender and Bureaucracy. Oxford: Blackwell.

Schweitzer, Sylvie (2010). Femmes de pouvoir, une bistoire de l'égalité professionnelle en Europe (19e-20e siècle). Paris: Payot.

Singly (de), François, and Thélot, Claude (1988). Gens du privé, gens du public. La grande différence. Paris: Dunod.

Simek-Pouydesseau, Jeanne (2013). "Le recrutement des femmes dans les concours de catégorie A: La source des viviers". Revue Française d'Administration Publique, 145: 65-88.

Wajcman, Judy (1998). Managing like a Man: Women and Men in Corporate Management. University Park: Pennsylvania State University Press. 